\title{
Dynamic Consequences of the 1997 NFC Award: Provincial Social Sector Expenditures
}

\author{
MUHAMMAD SABIR
}

\section{INTRODUCTION}

An adequate provision of social services is a concurrent function of federal and provincial governments. However, in Pakistan, the financing and delivery of social services largely prevails in the hands of provinces and major sources of revenues in the hand of federal government, which creates vertical imbalances. Federal transfers are the mechanism for their correction and these are constituted through the National Finance Commission (NFC) Awards. The last NFC Award was constituted in 1997 and it changed both the size of divisible pool and the share of federal and provincial governments in the divisible pool. The changed provincial shares have based on higher tax revenue collection, which was not materialised during the following four-year period after the award. Therefore, provincial governments experienced the shortfall in the federal transfers during last four years after the award and have experienced a lower growth in transfers than projected in 1997 NFC Award. This is in contrast with the provincial experience during 1991 NFC Award, in which provinces had received higher revenue transfers from federal government than projected.

The shortfall in federal transfers put uneasy pressure on provincial finances and left provincial governments with three options: increase efforts to mobilise higher revenues from own resources, curtailed expenditure and finally increase borrowing. On the one hand, in the presence of poor macroeconomic performance and persistence drought especially in the last year minimises the scope of increase in efforts to mobilise higher revenues from provincial own resources minimised the scope for first option. On the other hand, to protect some heads of public expenditures, 1997 NFC Award bifurcates public expenditure into priority and nonpriority expenditures. Current expenditure on social sector, debt servicing and

Muhammad Sabir is an Economist at the Social Policy and Development Centre (SPDC), Karachi. Author's Note: The author gratefully acknowledges the comments and suggestions of Dr Hafiz A. Pasha, Director, Regional Bureau for Asia and Pacific, UNDP, and also the PSDE conference participants, specialty Qazi M. Alimullah, formerly Secretary, Government of Pakistan, and M. Aslam Khan of the Planning and Development Division, Government of Pakistan. 
development expenditure were called priority expenditures while the remaining current expenditures included expenditures on law and order, community services, general administration were called non-priority expenditures. The idea of this bifurcation is to protect priority expenditures in case of any shortfall in revenues. Four-year experiences demonstrate that debt-servicing obligations were fulfilled by provinces and the shortfall in revenues generally translated on development expenditures. However, ambiguity occurs in case of social sector expenditure that leads to the following question. Have social sector expenditures been protected during the four period or not? Alternatively, what is the impact of 1997 NFC Award on social sector expenditures?

The estimated expenditure response of provincial governments after the 1997 NFC Award is the focus of this paper. Estimating responsiveness raises an interesting empirical question, which has been largely ignored in intergovernmental transfers literature. The question is whether the expenditure response to changes in the design of intergovernmental transfers is symmetrical. In other words, is its magnitude the same for both social services expenditures and other expenditures? Previous empirical studies have not distinguished whether the social services expenditures or other expenditures affected largely in case of any increase or decrease in the federal transfers to provinces. This paper hypothesises that provincial responses in case of change in design of federal transfers are asymmetric. Asymmetric provincial expenditure response may occur for a number of reasons. Primarily, expenditure on social services is generally considered as a source of poverty reduction. Second, expenditure on social services especially at primary or basic level is considered to be subject to high external benefits. Third, social services expenditures are the focal point of Social Action Plan (SAP I\&II). Finally, one of the main objectives of the 1997 NFC Award was to protect priority expenditures including social services expenditures. The 1997 NFC Award offers a good opportunity to test asymmetric response hypothesis for provincial government expenditures.

The next section provides descriptive statistics on provincial expenditure trends, a comparative structure of provincial resources before and after 1997 NFC Award. Then a micro-theoretic model of provincial expenditures is developed and estimated. Finally, some concluding comments are offered.

\section{COMPARATIVE GROWTH IN PROVINCIAL REVENUES AND EXPENDITURES}

This section offers summery statistics of comparative growth rates on provincial revenues and expenditures before and after 1997 NFC Award. It reports a set of combined aggregated descriptive statistics of four provinces. ${ }^{1}$

\footnotetext{
${ }^{1}$ Horizontal analysis is beyond the purview of this paper.
} 
Provincial revenues can be divided into two broad categories; own revenues receipts and federal transfers and grants. Table 1 shows that growth in provincial general revenues declined after the 1997 NFC Award. This is the outcome of both change in design of federal transfers to the provinces and low tax collection. The overall decline in the growth of provincial general revenue receipts is more than 9 percent, which is largely the outcome of sizeable decline (over 10 percent) in federal transfers. Federal tax assignment experienced the largest decline in growth of over 19 percent. After 1997 NFC Award growth in provincial tax receipts declined by 4 percent due to poor performance in agriculture sector mainly because of drought. However, increase in growth rate of federal development and non-development grants diluted the impact of lower growth in other sources of revenues.

Table 1

Pre- and Post-1997 NFC Award Growth Rate of Revenues and Expenditures (Aggregate of Four Provinces Combined)

\begin{tabular}{|c|c|c|c|}
\hline & $\begin{array}{c}\text { Pre } 1997 \text { NFC } \\
\text { Award } \\
\end{array}$ & $\begin{array}{c}\text { Post } 1997 \\
\text { NFC Award }\end{array}$ & \multirow{2}{*}{$\frac{\text { Difference }}{\text { In Growth }}$} \\
\hline & $\begin{array}{c}\text { FY } 1992 \text { to } \\
\text { FY } 1997\end{array}$ & $\begin{array}{l}\text { FY } 1998 \text { to } \\
\text { FY } 2001\end{array}$ & \\
\hline & ACGR (\%) & ACGR (\%) & Rates \\
\hline General Revenue Receipts & 17.8 & 8.7 & -9.1 \\
\hline Total Provincial Own Receipts & 11.7 & 9.4 & -2.3 \\
\hline Provincial Tax Receipts & 13.3 & 9.3 & -4.0 \\
\hline Provincial Non-tax Receipts & 9.9 & 9.4 & -0.5 \\
\hline Federal Transfers and Grants* & 19.1 & 8.5 & -10.6 \\
\hline Federal Tax Assignment & 26.5 & 7.0 & -19.5 \\
\hline \multicolumn{4}{|l|}{ Federal Non Development } \\
\hline Grants & 57.4 & 62.0 & 4.6 \\
\hline Federal Development Grants & -9.7 & 5.5 & 15.2 \\
\hline Current Expenditure & 15.6 & 9.7 & -5.9 \\
\hline Debt Servicing & 11.1 & 5.8 & -5.2 \\
\hline Service-related Expenditure & 16.9 & 10.5 & -6.4 \\
\hline Social Sectors & 18.0 & 5.7 & -12.3 \\
\hline Other Sectors & 16.0 & 14.3 & -1.8 \\
\hline Development Expenditure & 2.0 & 8.7 & 6.7 \\
\hline Social Sectors & 7.3 & -2.9 & -10.2 \\
\hline Other Sectors & -2.9 & 20.0 & 22.9 \\
\hline
\end{tabular}

Source: Various Provincial Annual Budget Statements.

* Included devisable pool transfers, straight transfers and Profit from Hydroelectricity.

ACGR= Annual Compound Growth Rate. 
The provincial expenditures growth rates portray an interesting picture. According to which without exception each and every component of provincial current expenditures experienced slow growth after 1997 NFC Award. This is the outcome of the government policy to reduce public expenditure at all levels, coupled with low growth in general revenue receipts. Another interesting aspect is the higher growth in other services related expenditures component of development expenditures.

\section{The Key Elements of the 1997 NFC Award}

1997 NFC Award was innovative in nature and changed intergovernmental fiscal transfers mechanism at large scale. This award differed with the previous awards in many ways and introduced some new ideas in the design of federal transfers. First and the foremost, this award recognised the common resource pool problem faced by Pakistan. The recognition of common pool problem is new in the literature of fiscal federalism and also highlighted by De Mello and Luiz (2000) in the context of other developing countries. This recognition in Pakistan led toward the formation of the National Resource Picture, which was based on the projected values of all sources of revenues included tax, non-tax revenues and borrowing of both tiers of governments.

The other major step, which we already highlighted, is bifurcation of expenditures into priority and non-priority expenditures. Priority expenditures contained expenditures on defence, debt servicing, social services and development. The reaming head of expenditures including economic services, community services, general administration etc. were categorised as non-priority expenditures. The basic idea behind this bifurcation was to protect priority expenditures in case of any decline in resources, without damaging the national interest of the country.

The estimation of provincial shares was based on a four step methodology. As the first step, provincial expenditures were projected till 2001-02, based on the benchmarks chosen by provincial representatives. Secondly, national resources were projected for the same period. Based on these projections, provincial share was then estimated, which is equivalent to all provincial current expenditures and fifty percent of development expenditures. Finally, to address horizontal imbalances constitutional subventions were allocated to relatively backward provinces NWFP and Balochistan.

Table 2 highlights the change in provincial share in divisible pool since the separation of East Pakistan. Table 2 conveyed that 1991, NFC Award increased the share of provinces by including federal excise duty on tobacco and sugar. Another, important point which emerges from Table 2 is that provinces had gotten 80 percent of two major federal taxes "Sales Tax" and "Income and Corporation Tax", which were the focus of tax and tariff reforms initiated in early 90s. 
Table 2

Provincial Share in Federal Taxes

\begin{tabular}{|c|c|c|c|c|}
\hline & Divisible Pool & NFC 1974 & NFC 1991 & NFC 1997 \\
\hline \multirow[t]{2}{*}{ A. } & Income Tax and & & & \\
\hline & Corporation Tax & $80 \%$ & $80 \%$ & $37.5 \%$ \\
\hline B. & Other Direct Taxes & - & - & $37.5 \%$ \\
\hline C. & Sales Tax & $80 \%$ & $80 \%$ & $37.5 \%$ \\
\hline \multirow[t]{3}{*}{ D. } & Central Excise Duty & & & $37.5 \%$ \\
\hline & - Tobacco & - & $80 \%$ & \\
\hline & - Sugar & & $80 \%$ & \\
\hline E. & Import Duties & - & - & 37.5 \\
\hline \multirow[t]{2}{*}{ F. } & Export Duties & & & - \\
\hline & - Cotton & $80 \%$ & $80 \%$ & \\
\hline
\end{tabular}

Source: Pakistan (1997).

In contrast, 1997 NFC Award included all federal taxes in divisible pool and decreased the provincial share from 80 percent to 37.5 percent, which is less than half of previous share. This change was based on optimistic targets based on certain macroeconomic projections like GDP growth, inflation etc. and higher expectations from tax and tariff reforms. However, during the four-year period these expectations did not materialise due to many external and internal shocks, which largely affected federal tax collection.

Table 3 highlights both the effect of these external and internal shocks, and the impact of change in design on real federal transfers to the provinces. The projected amount of federal transfers and constitutional subventions at constant rupees of 1980-81 were Rs 40.9 billion but in reality, it turned out only Rs 32.3 billion. The shortfall increased with passage of time and reached its peek during 2000-01, in which projected, real transfers were Rs 55.6 billion but provinces received only Rs 38.3 billion.

To quantify the impact of change in design of federal transfers we projected federal transfers by using the formula of 1991 NFC Award based on projected revenues of 1997 NFC Award. Table 3 also reveals that if the pervious formula of 1991 NFC Award were to continue then provinces would get higher revenues as a result of higher share of buyont taxes. Similarly, the impact of change in design also increased in the later years. 
Table 3

Real Federal Transfers to Provinces

\begin{tabular}{|c|c|c|c|c|}
\hline & 1997-98 & 1998-99 & $1999-2000$ & $2000-01$ \\
\hline \multicolumn{5}{|l|}{ Divisible Pool Transfers } \\
\hline Actuals & 25,532 & 24,992 & 27,494 & 30,111 \\
\hline 1997 NFC Award Projections & 33,280 & 36,481 & 40,822 & 46,691 \\
\hline Projections As Per 1991 NFC Award* & 38,941 & 43,304 & 49,498 & 58,920 \\
\hline \multicolumn{5}{|l|}{ Straight Transfers** } \\
\hline Actuals & 4,986 & 4,602 & 5,733 & 6,369 \\
\hline 1997 NFC Award Projections & 5,816 & 5,992 & 6,294 & 6,742 \\
\hline As Per 1991 NFC Projections & 5,816 & 5,992 & 6,294 & 6,742 \\
\hline \multicolumn{5}{|l|}{ Constitutional Subvention } \\
\hline Actuals & 1,812 & 1,904 & 1,943 & 1,836 \\
\hline 1997 NFC Award Projections & 1,814 & 1,904 & 2,040 & 2,171 \\
\hline As Per 1991 NFC Projections & - & - & - & - \\
\hline \multicolumn{5}{|l|}{ Total Transfers } \\
\hline Actuals & 32,329 & 31,498 & 35,169 & 38,315 \\
\hline 1997 NFC Award Projections & 40,910 & 44,376 & 49,156 & 55,605 \\
\hline As Per 1991 NFC Projections & 44,757 & 49,296 & 55,792 & 65,662 \\
\hline
\end{tabular}

Table 4 presents the two types of descriptive statistics. First, it highlights the shortfall, which occurred in federal transfers due to low tax collection. This is the difference between actual federal transfers. The shortfall increased after the nuclear blast and reached its peak during 2000-01. In real terms the impact of low tax collection increased from Rs 8.6 billion to Rs 17.3 billion more than double just in a four-year period. The impact of low tax collection was dominated on divisible pool transfers.

Second, Table 4 highlights the impact of 1997, NFC Award on federal transfers. This is the difference between 1997 NFC Award projected federal transfers to the provinces and estimated transfers based on projected revenues of 1997 NFC Award by using the formula of the 1991 NFC Award. According to this, provinces can get Rs 3.8 billion more than actual transfers in real terms during 1997-98 which further increased to over Rs 10 billion during the year 2000-01. This large difference occurred due to higher growth in sales tax and, income and corporate tax. Consequently, the provinces were largely affected by the low tax collection as compared to change in design. 
Table 4

Change in Real Federal Transfers to Provinces

(Rs Million)

\begin{tabular}{lcccc}
\hline & & & & (Rs Million) \\
\hline Divisible Pool Transfers & $1997-98$ & $1998-99$ & $1999-2000$ & $2000-01$ \\
$\quad$ Impact of Low Tax Collection & $-7,748$ & $-11,489$ & $-13,328$ & $-16,581$ \\
Imapct of Change in Transfer's Design & $-5,661$ & $-6,823$ & $-8,676$ & $-12,228$ \\
$\quad$ Total & $-13,409$ & $-18,312$ & $-22,004$ & $-28,809$ \\
Straight Transfers & & & & \\
$\quad$ Impact of Low Tax Collection & -831 & $-1,390$ & -561 & -373 \\
$\quad$ Imapct of Change in Transfer's Design & 0 & 0 & 0 & 0 \\
$\quad$ Total & -831 & $-1,390$ & -561 & -373 \\
Constitutional Subvention & & & & \\
$\quad$ Impact of Low Tax Collection & -2 & 0 & -97 & -335 \\
$\quad$ Imapct of Change in Transfer's Design & 1,814 & 1,904 & 2,040 & 2,171 \\
$\quad$ Total & 1,812 & 1,904 & 1,943 & 1,836 \\
Overall Impact & & & & \\
$\quad$ Impact of Low Tax Collection & $-8,580$ & $-12,879$ & $-13,987$ & $-17,289$ \\
Imapct of Change in Transfer's Design & $-3,848$ & $-4,919$ & $-6,636$ & $-10,057$ \\
$\quad$ Total & $-12,428$ & $-17,798$ & $-20,623$ & $-27,347$ \\
\hline Source: Estimates based on Table 3. & & & & \\
& & & &
\end{tabular}

\section{DYNAMIC CONSEQUENCES OF THE 1997 NFC AWARD}

The treatment of the 1997, NFC Award to this point has been explicitly based on descriptive statistics. Although these statistics provided a broad picture of the implications of 1997 NFC Award but this broad picture is incomplete without any empirical findings. Unfortunately, we do not have many empirical studies that bring to bear on the matter of intergovernmental transfers. There is a substantial descriptive literature addressing the many aspects of the intergovernmental transfers with respect to fiscal competition among the sub-national governments [Musgrave (1997)], market incentive of federalism [Qian and Weingast (1997)], intergovernmental transfers and deadweight losses in tax system [Smart (1996)], and finally coordination failure [De Mello and Luiz (2000)]. However, this body of work really does not shed much light on the normative question of dynamic consequences of any change in designed mechanism of intergovernmental transfers on provincial finances.

In an interesting study that is of relevance here, Ghaus and Pasha (1996) find evidences of strategic interaction in intergovernmental transfers and provincial expenditures. They developed an econometric model for Pakistan to evaluate the consequence of the NFC Award 1991. The model thoroughly studied the fiscal 
relationship between the provinces and federal government and, highlighted the key features of provincial finances. However, their study did not bifurcate expenditure and just estimated the overall impact of transfers on total expenditure. In contrast, this paper has developed a model to analyse the impact of intergovernmental transfers and other federal grants on social sector expenditures.

\section{Methodological Framework}

The methodological framework based on the assumption that politicians/officials want to maximise the utility of the typical consumer (median consumer) in their jurisdiction subject to budget constraint. For the sake of simplicity, consumption basket of typical citizen (median consumer) can be divided into two broad groups; publicly provided goods and services $(A)$, and privately provided goods and services $(B)$. Utility was assumed to depend positively on the quantity of goods and services provided by the provincial government $(A)$ and on the level of consumption of private goods (B).

$$
U=U\left(Q_{A}, Q_{B}\right)
$$

The goods and services provided by provincial government can be split into social services and, other goods and services

$$
U=U\left(Q_{S}, Q_{O}, Q_{B}\right)
$$

The quantity of demand of each good and services depends upon the expenditure on it. In the case of private goods and services, expenditure would be equal to real per capita disposable income of the consumer or $(y-R)$, where $y$ is the real per capita income and $R$ is the real per capita revenue received by the government. Similarly, in the case of publicly provided goods and services, expenditure would be equal to provincial expenditure on social services (SE) and other services $(O E)$. Therefore, the utility function can be rewritten as

$$
U=U(S E, O E, Y-R) \quad \ldots \quad \ldots \quad \ldots \quad \ldots \quad \ldots
$$

$R$ includes both tax and non-tax revenues, while $S E$ and $O E$ consist of both recurring, and development expenditures on publically provided social services and other services. We exclude the payments for servicing of debt, as these do not benefited citizens directly through provision of services.

The sources of revenues for provincial governments except its own revenues are federal transfers from divisible pool, development and non-development grants and borrowings. Therefore, the budget constraint of the provincial government (at current prices) can be expressed as: 


$$
p_{2}(S E+O E)=p_{1} R+\bar{T}+\bar{B}+G \quad \ldots \quad \ldots \quad \ldots
$$

Where $Y=$ real per capita income.

$R=$ real per capita provincial revenue (include both tax and non-tax revenues).

$\mathrm{SE}=$ real per capita social sector expenditures (both recurring and development).

$O E=$ real per capita other expenditures (both recurring and development).

$P_{1}=$ General Price Level (CPI).

$P_{2}=$ price index of public expenditure.

$T=$ per capita total intergovernmental transfers.

$B=$ per capita borrowing by the provincial government.

$G$ consisted of two types of grants from federal government to provincial governments. These are lump sum grants (heavily consists of development grants) and deficit grant (heavily consists of non-development and non-obligatory grants). Therefore, by definition, total flow of grants was given as:

$$
G=G_{0}+m\left[p_{2}(S E+O E)-p_{1} R-\bar{T}-G_{0}\right], 0 \prec m \prec 1 \quad \ldots \quad \ldots
$$

Where $\mathrm{m}=$ proportion of the revenue deficit financed by deficit grants.

Deficit grant was played a very significant role in the provincial finances before 1991 but after that, this option was curtailed in the 1991 NFC Award. However, lump sum grants are still provided to the provinces for their development projects.

Substituting (3) into (2) we obtain,

$$
p_{2}(S E+O E)=p_{1} R+\bar{T}+\overline{G_{0}}+G_{D}+\bar{B} \quad \ldots \quad \ldots \quad \ldots
$$

After addition of $\mathrm{p}_{1} \mathrm{y}$ on both sides of the equation (4) budget constraint can be written as:

$$
P_{1}(Y-R)+p_{2} S S E+p_{2} O S E=p_{1} Y+\bar{T}+\bar{G}_{0}+G_{D}+\bar{B} \quad \ldots \quad \ldots
$$

Based on the above set of equations, a utility maximisation problem can be set up as follows:

$$
\ell(R, S E, O E, \lambda)=U(Y-R, S E, O E)+\lambda\left[I-p_{1}(Y-R)-p_{2}(S E+O E)\right] \ldots
$$

Where $I=P_{1} Y+T+G_{0}+G_{D}+B$

The first order conditions are as follows: 


$$
\begin{array}{cccccc}
\frac{\partial \ell}{\partial R}=-\frac{\partial U}{\partial(Y-R)}+\lambda p_{1}=0 & \ldots & \ldots & \ldots & \ldots & \ldots \\
\frac{\partial \ell}{\partial S E}=\frac{\partial U}{\partial S E}-\lambda p_{2}=0 & \ldots & \ldots & \ldots & \ldots & \ldots \\
\frac{\partial \ell}{\partial O E}=\frac{\partial U}{\partial O E}-\lambda p_{2}=0 & \ldots & \ldots & \ldots & \ldots & \ldots \\
\frac{\partial \ell}{\partial \lambda}=I-p_{1}(Y-R)-p_{2}(S E+O E)=0 & \ldots & \ldots & \ldots & \ldots
\end{array}
$$

The above derivation based on micro-theoretic approach provides the information on the signs of partial derivatives of the function, but it needs an explicit utility function for estimation purposes. In the analysis of consumer behaviour, many utility functions were used and among them, we chose the analogous Stone-Geary utility function for the estimation of the model.

$$
\begin{aligned}
& U=\left(S E-S E_{0}\right)^{\alpha_{1}}\left(O E-O E_{0}\right)^{\alpha_{2}}\left(y-R-y_{0}\right)^{\left(1-\alpha_{1}-\alpha_{2}\right)} \ldots \\
& 0 \prec \alpha_{1} \prec 1, \\
& 0 \prec \alpha_{2} \prec 1, \\
& 0 \prec \alpha_{1}+\alpha_{2} \prec 1
\end{aligned}
$$

The Stone-Geary utility function has particular advantages over other functions. The most important advantage of the Stone-Geary utility function is the inclusion of $y_{0}, S E_{0}$, and $O E_{0}$, which are "minimum survival bundles" and ensure the subsistence level of consumer demand for public and private goods and services. Substituting the derivatives of utility function into (7), (8) and (9) respectively, yields

$$
\begin{array}{cccccc}
P_{1}(Y-R)=\frac{\left(1-\alpha_{1}-\alpha_{2}\right) U}{\lambda}+P_{1} Y_{0} & \ldots & \ldots & \ldots & \ldots \\
P_{2} S E=\frac{\alpha_{1} U}{\lambda}+P_{2} S E_{0} & \ldots & \ldots & \ldots & \ldots & \ldots \\
P_{2} O E=\frac{\alpha_{2} U}{\lambda}+P_{2} O E_{0} & \ldots & \ldots & \ldots & \ldots & \ldots
\end{array}
$$

Substituting the value of $p_{2} S E, p_{2} E$ and $p_{1}(Y-R)$ from (12), (13) and (14) into (5) we obtained 


$$
\frac{U}{\lambda}=p_{1}\left(Y-Y_{0}\right)+T+G_{0}+\frac{B}{1-m}-p_{2}\left(S E_{0}+O E_{0}\right) \quad \ldots \quad \ldots
$$

Minimum bundle of income $y_{0}$ was assumed to be partly constant and partly rises with income $y$.

$$
y_{0}=a_{0}+a_{1} y
$$

Therefore, Equation 19 can be written as:

$$
\frac{U}{\lambda}=\left(1-a_{1}\right) p_{1} Y-a_{0} p_{1}+T+G_{0}+\frac{B}{1-m}-P_{2}=\left(S E_{0}+O E_{0}\right) \ldots \quad \ldots
$$

After substituting the value from equation 16 into 12, 13 and 14, we finally have the following system of equation for estimation:

$$
\begin{aligned}
& p_{2} S E=\alpha_{1}\left(1-\alpha_{1}\right) p_{1} Y-\alpha_{0} \alpha_{1} p_{1}+\alpha_{1}\left(T+G_{0}\right)+\frac{\alpha_{1}}{1-m} B+ \\
& \left\{\left(1-\alpha_{1}\right) S E_{0}-\alpha_{1} O E_{0}\right\} p_{2} \ldots \quad \ldots \quad \ldots \quad \ldots \quad \ldots \\
& p_{2} O E=\alpha_{2}\left(1-\alpha_{1}\right) p_{1} Y-\alpha_{0} \alpha_{2} p_{1}+\alpha_{2}\left(T+G_{0}\right)+\frac{\alpha_{2}}{1-m} B+ \\
& \left\{\left(1-\alpha_{2}\right) O E_{0}-\alpha_{2} S E_{0}\right\} p_{2} \quad \ldots \quad \ldots \\
& p_{1} R=\left(\alpha_{1}+\alpha_{2}\right)\left(1-\alpha_{1}\right) p_{1} Y+\alpha_{0}\left(\alpha_{1}+\alpha_{2}\right) p_{1}-\left(1-\alpha_{1}-\alpha_{2}\right)\left(T+G_{0}\right)- \\
& \frac{\left(1-\alpha_{1}-\alpha_{2}\right)}{1-m} B+\left(1-\alpha_{1}-\alpha_{2}\right)\left(S E_{0}+O E_{0}\right) p_{2} \quad \ldots \quad \ldots
\end{aligned}
$$

Equations (17) and (18) are the desired expenditure equations. Divided both equations by $p_{2}$ we have following functional form:

$$
\begin{aligned}
& S E=\alpha_{1}\left(1-\alpha_{1}\right) \frac{p_{1} Y}{p_{2}}-\alpha_{0} \alpha_{1} \frac{p_{1}}{p_{2}}+\alpha_{1} \frac{\left(T+G_{0}\right)}{p_{2}}+\frac{\alpha_{1}}{(1-m)} \frac{B}{p_{2}}+ \\
& \left\{\left(1-\alpha_{1}\right) S E_{0}-\alpha_{1} O E_{0}\right\} \quad \ldots \quad \ldots \quad \ldots \quad \ldots \\
& O E=\alpha_{2}\left(1-\alpha_{1}\right) \frac{p_{1} Y}{p_{2}}-\alpha_{0} \alpha_{2} \frac{p_{1}}{p_{2}}+\alpha_{2} \frac{\left(T+G_{0}\right)}{p_{2}}+\frac{\alpha_{2}}{(1-m)} \frac{B}{p_{2}}+ \\
& \left\{\begin{array}{llllll}
\left.\left(1-\alpha_{2}\right) O E_{0}-\alpha_{2} S E_{0}\right\} & \ldots & \ldots & \ldots & \ldots
\end{array}\right.
\end{aligned}
$$

After 1991 NFC Award value of $m$ became zero 


$$
\begin{aligned}
& S E=\alpha_{1}\left(1-\alpha_{1}\right) \frac{p_{1} Y}{p_{2}}-\alpha_{0} \alpha_{1} \frac{p_{1}}{p_{2}}+\alpha_{1} \frac{\left(T+G_{0}+B^{*} D 92\right)}{p_{2}}+\frac{\alpha_{1}}{(1-m)} \\
& \frac{B^{*} D 91}{p_{2}}+\left\{\left(1-\alpha_{1}\right) S E_{0}-\alpha_{1} O E_{0}\right\} \quad \ldots \quad \ldots \quad \ldots \quad \ldots \quad \ldots \\
& O E=\alpha_{2}\left(1-\alpha_{1}\right) \frac{p_{1} Y}{p_{2}}-\alpha_{0} \alpha_{2} \frac{p_{1}}{p_{2}}+\alpha_{2} \frac{\left(T+G_{0}+B^{*} D 92\right)}{p_{2}}+\frac{\alpha_{2}}{(1-m)} \\
& \frac{B^{*} D 91}{p_{2}}+\left\{\left(1-\alpha_{2}\right) O E_{0}-\alpha_{2} S E_{0}\right\} \quad \ldots \quad \ldots \quad \ldots \quad \ldots \quad \ldots
\end{aligned}
$$

The value of $D 91$ is 1 prior to 1991 NFC Award otherwise zero and, value of D92 is 1 after the 1991 NFC Award, other wise zero

Due to the limitation on availability of the basic data (for example, the data of provincial gross domestic products are not available), we are unable to conduct a province wise analysis. Therefore, the above model has been estimated for the four provincial governments combined. Annual budget statements of the individual provinces have been used to generate the aggregate database for key provincial budgetary magnitudes.

Equations (22) and (23) were estimated for the period, 1972-73 to 2000-01. Results of estimation are as follows:

$$
\begin{aligned}
& S E=-0.2423+0.0264 \frac{P_{1} Y}{p_{2}}-0.2212 \frac{p_{1}}{p_{2}}+0.1851 \frac{\left.T+G_{0}+B * D 92\right)}{p_{2}}+ \\
& (-2.57)^{*}(7.23)^{*} \quad(-2.09)^{*} \quad(5.55) * \\
& 0.3266 \frac{B^{*} D 91}{p_{2}}+0.1814 D U M 1 \\
& (6.26)^{*} \quad(12.34)^{*} \\
& \bar{R}^{2}=0.984 \quad \text { D.W Statistic }=1.785 \\
& O E=-0.7258+0.0151 \frac{P_{1} Y}{p_{2}}-0.4733 \frac{p_{1}}{p_{2}}+0.1635 \frac{\left(T+G_{0}+B^{*} D 92\right)}{p_{2}}+ \\
& (3.46)^{*} \quad(1.84) \quad(-2.19)^{*} \quad(2.17)^{*} \\
& 0.4215 \frac{B^{*} D 91}{p_{2}}+0.2143 D U M 2 \\
& (3.53)^{*} \quad(3.13)^{*} \\
& \bar{R}^{2}=0.840 \quad \text { D.W Statistic }=1.47 \\
& t \text {-statistic in parenthesis } \quad * \text { Significant at } 5 \text { percent level }
\end{aligned}
$$


All estimated signs are consistent with the developed model. Each coefficient, except the income $(y)$ in other expenditure $(O E)$ equation is significantly different from zero at a five-percent significance level with a $t$-test. The value of adjusted $\mathrm{R}^{2}$ indicates that the first model explain almost 98 percent variation and second model explain almost 84 percent variation in provincial social and other expenditures. The estimated coefficients of Equations 22 and 23 can be used to draw the inferences about the behaviour of provincial governments.

According to the estimates of Equations 22 and 23, impact of any increase or decrease in federal transfers is relatively higher on social sector expenditures. One rupee increase or decrease in either real federal transfers or lump sum grants or borrowing can affect 18.51 paisas to social sector expenditures and 16.35 paisas to other provincial expenditures in real terms. In general, these estimated coefficients of federal transfers reflect that almost 35 percent real provincial service related expenditures depends on federal transfers. The remaining 65 percent of federal transfers are translated on either debt servicing or reduction in efforts of resource mobilisation. The fact of low resource mobilisation efforts at provincial level is also reflected from the coefficient of income, which has the meager values of 0.026 and 0.015 . In other words, one rupee increase in income translated to less than three paisas in real social sector expenditures and less than two paisas in other services related expenditures.

The NFC Award 1991 truncated the option of deficit grants for the provincial budget deficits, which was previously available and fully utilised by the provinces. This truncation of deficit grants reflected through the behaviour of the provinces in the utilisation of the debt. To capture the effect of truncation of deficit grants on utilisation of debt, we used two interactive dummies D91 (one for 1972-73 to 1990-91 otherwise zero) and D92 (zero for 1972-73 to 1990-91 otherwise one). The coefficient of debt interacted with $D 91$ reveals that until 1991 a large component of debt translated into provincial expenditures, in the areas of either expenditure on social services or other services. However, elimination of deficit grants changed the provincial behaviour after 1991. Provinces used borrowings in a way similar to federal transfers and grants. This change is largely affected other services related expenditures. The coefficient of debt reduced after 1991 from 0.3266 to 0.1851 in social services and from 0.4215 to 0.1635 in other services related expenditures. This change clearly demonstrates that the provincial government started utilisation of debt to finance debt servicing.

Finally, inflation negatively affects real social and other expenditures largely. The impact of inflation is higher on other expenditures as compared to social services. The other contributors in growth of provincial expenditures are captured through $D U M 1^{2}$ and $D U M 2^{3}$ both are positive and significant. In the growth of

${ }^{2}$ DUM 1 has values 1 for $1985-86,1.25$ for $86-87,1.5$ for $87-88$ and 0.75 for $88-89$ for five point programme, 0.25 for $1993-94$, .40 for $94-95$, 0.5 for $95-96$ and 0.25 for $96-97$ for SAP-I and -0.75 in 2000-01 for drought.

${ }^{3}$ DUM2 has 1 in 1992-93 base year of SAP-1 and 1 in 2000-01 for drought. 
social sector expenditures, major contributors were the five-point programme, Social Action Programme-I, while drought affected social sector expenditure negatively. In contrast, other expenditures were higher during 1992-93 and 2000-01. 1992-93 was the base year for SAP-I and 2000-01 is the drought year. During drought year provinces, spend more on social safety nets and other schemes of water managements.

Given the above result, we are now in the position to conduct comparative analysis on the dynamic consequences of 1997 NFC Award on provincial real social sector and other services related expenditures. Table 5 provides the estimated shortfall in provincial real social and other services related expenditures due to shortfall in federal transfers. The estimates shows that the impact of low tax collection is greater on real social sector expenditures as compared to other services related expenditures. In 1997-98, low tax collections dented social services expenditures by more than Rs 1.5 billion and its impact further increased to over Rs 3.2 billion in 2000-01. In contrast, the impact of change in design was not significant in 1997-98. However, in 2000-01 impact of change in design also increased to Rs. 1.8 billion.

Other services related expenditures also experienced a greater decline in later years. Decline in other real provincial services related expenditures is lower than real social sector expenditures. In 1997-98 the combined impact of low tax collection and change in design on other expenditures was around Rs 2 billion, which rose to approximately Rs 4.5 billion in 2000-01.

Table 5

Dynamic Consequences of the 1997 NFC Award for the Provincial Real Social Sector and Other Services-related Expenditures

(Rs Million)

1997-98 1998-99 1999-2000 2000-01

Social Sector Expenditures

$\begin{array}{lcccc}\text { Impact of Low Tax Collection } & -1,588 & -2,384 & -2,589 & -3,201 \\ \text { Impact of Change in Transfer's Design } & -712 & -911 & -1,229 & -1,862 \\ \text { Total } & -2,301 & -3,295 & -3,818 & -5,063\end{array}$

Other Expenditures

$\begin{array}{lcccc}\text { Impact of Low Tax Collection } & -1,403 & -2,106 & -2,287 & -2,827 \\ \text { Impact of Change in Transfer's Design } & -629 & -804 & -1,085 & -1,645 \\ \text { Total } & -2,032 & -2,910 & -3,372 & -4,472\end{array}$

Source: Author’s Estimates. 
However, a comparison of social services and other expenditures in absolute terms did not portray the true picture. Therefore, we estimated relative impact of these changes on social and other services related expenditures. Table 6 highlights the relative comparative statistics, which clearly shows the impact of low tax collection and change in design is much greater on social services expenditures.

Table 6

Dynamic Consequences of the 1997 NFC Award for Provincial Real Social Sector and Other Services-related Expenditures

\begin{tabular}{|c|c|c|c|c|}
\hline & $1997-98$ & $1998-99$ & $1999-2000$ & $2000-01$ \\
\hline \multicolumn{5}{|l|}{ Social Sector Expenditures } \\
\hline Impact of Low Tax Collection & $-10.2 \%$ & $-15.9 \%$ & $-17.7 \%$ & $-23.7 \%$ \\
\hline Impact of Change in Transfer's Design & $-4.6 \%$ & $-6.1 \%$ & $-8.4 \%$ & $-13.8 \%$ \\
\hline Total & $-14.8 \%$ & $-22.0 \%$ & $-26.1 \%$ & $-37.5 \%$ \\
\hline \multicolumn{5}{|l|}{ Other Expenditures } \\
\hline Impact of Low Tax Collection & $-8.1 \%$ & $-12.5 \%$ & $-11.7 \%$ & $-13.2 \%$ \\
\hline Impact of Change in Transfer's Design & $-3.6 \%$ & $-4.8 \%$ & $-5.5 \%$ & $-7.7 \%$ \\
\hline Total & $-11.7 \%$ & $-17.2 \%$ & $-17.2 \%$ & $-20.9 \%$ \\
\hline
\end{tabular}

Source: Author's Estimates.

According to the estimates of Table 6 combined impact of low tax collection and change in design was around 15 percent in 1997-98 that further increased to 37.5 percent in 2000-01. However, the combined impact of low tax collection and change in design on other services related expenditures was roughly 12 percent in 1997-98 that increased to roughly 21 percent in 2000-01.

\section{CONCLUSION}

In contrast to the objective of the 1997 NFC Award, bulk of the shortfall in federal transfers to provinces translated into real social sector expenditures, which experienced slow growth and a large deviation from the trend. According to the estimates based on micro-theoretic model, any decline in real transfers largely affected real social sector expenditures. In a nut shell, bifurcation of public expenditure into priority and non-priority expenditures in the 1997 NFC Award failed to protect social sector expenditures.

\section{REFERENCES}

De Mello Jr., and R. Luiz (2000) Fiscal Decentralisation and Intergovernmental Fiscal Relations: A Cross-Country Analysis. World Development 28:2, 365-380.

Ghous, A. F. Aisha (1996) Intergovernemntal Revenue Sharing in Pakistan. Social Policy and Development Centre. (Research Report No. 8.) 
Ghous, A. F. Aisha, and Hafiz A. Pasha (1994) Dynamic Budgetary Consequences of the 1991 NFC Award. The Pakistan Development Review 33:4, 627-645.

Musgrave, Richard A. (1997) Devolution, Grants, and Fiscal Competition. The Journal of Economic Perspectives 11: 4, 65-72.

Pakistan, Government of (1996) Report of the National Finance Commission. National Finance Commission, Secretariat. Islamabad.

Qian, Yingy, and Barry R. Weingast (1997) Federalism as a Commitment to Preserving Market Incentives. The Journal of Economic Perspectives 11:4, 8392.

Smart, Michael (1996) Taxation Incentives and Deadweight Loss in a System of Intergovernmental Transfers. Department of Economics and Institute for Policy Analysis, University of Toronto, (Working paper number ut-ecipa-msmart-9603) July 22. 


\section{Comments}

The current division of fiscal powers in the Federation of Pakistan is one of the major causes of weakness in domestic resource mobilisation efforts. The revenue-sharing arrangements derived from the Government of India Act 1935 laid down the formula for distribution of revenue from divisible sources. After independence in 1947 these provisions were incorporated into successive constitutions, delineating the respective revenue-raising powers of the federal and provincial governments.

An analysis of revenue sharing arrangements in Pakistan indicates that the constitutional division of legislative, administrative and financial powers between the constituent units of the Federation like many other countries opted in favour of Federal form of Government have not produced a congenial environment for policymaking on improvement in relations between the federal and provincial governments. At both levels of government, groups wielding substantial political and bureaucratic power have influenced policy-making and policy implementation.

The fundamental weakness of 1991 National Finance Commission (NFC) Award was that it assigned generous revenues to the provincial governments without properly assessing its implication on domestic resource mobilisation efforts and financial requirements of the federal government to meet its constitutional obligations. Thus, implementation of 1991 Award has created a situation similar to that faced by Government of India after the promulgation of Government of India Act 1919. Under the 1919 revenue sharing arrangements States share in divisible pool has created financial imbalance between the Centre and the State Governments. The increased flow of shared resources to State Government weakened the Central Government financial position to the extent that the Central Government had to borrow from the State Governments, which undermined the Central Government Authority. The Government of India Act 1921 and subsequently Government of India Act 1935 were to correct the imbalance. The 1991 NFC has created a similar situation.

Soon after the implementation of 1991 NFC award the situation of public finance necessitated a fundamental re-examination of the issues relating to revenue sharing arrangements in manner that the distribution of revenues between the two levels of government should be to adequately protect priority expenditures on social services, debt servicing and defence. It was also necessary to build an incentive environment for higher resource mobilisation by all levels of government. 
The 1997 NFC Award may be seen as an effort to correct the situation. The Award approach of using the National Resource Picture for making governments revenue and expenditure projections and deriving thereby the fiscal transfers to the provinces based on their expenditure needs which cannot be financed from their own resources was an improvement over the traditional methodology, which involved projecting benchmark established both provincial current expenditure and own receipts.

The 1997 NFC Award ensured that the development expenditure needs of the provincial governments should be financed partially by divisible pool transfers. The Award assured provinces source of revenue for planning their budgets. Thus, the Award enhanced the fiscal autonomy of the provincial governments.

Comparison of 1997 NFC Award with any award should be made carefully. There are so many caveats. During the 1997 NFC period Pakistan economy experienced periods of slow growth and many internal and external shocks. The analysis of consolidated budget (federal and provincial) of the period indicates that increase in government revenues was substantially below the award projections. The shortfall in government revenues has contributed in sizeable reduction in the divisible resources to the provinces. As a result, growth in government expenditure, particularly development expenditure was well below the NFC projection. Expenditure on social sectors was also influenced because of the shortfall in resources.

The paper has not concentrated to a single issue. It focuses on many topics without much clarity. Nevertheless, it provides enough thinking for discussion and future research on the subject.

Planning Commission,

Muhammad Aslam Khan Government of Pakistan, Islamabad. 